Lena Hansson har en gymnasielärarutbildning och har arbetat som gymnasielärare i fysik och matematik. Hon är nu doktorand i naturvetenskapernas didaktik på Högskolan Kristianstad, Sverige. Hon är också en av doktoranderna i den svenska nationella forskarskolan i naturvetenskapernas och teknikens didaktik. Hennes forskningsintresse handlar om vilken typ av världsbilder som eleverna förknippar med naturvetenskapen och möjliga konsekvenser av detta för undervisning och lärande.

Andreas Redfors är docent i fysik vid Högskolan Kristianstad, Sverige. Han har en gymnasielärarutbildning samt har doktorerat i fysik vid Lunds universitet. Han undervisar fysik, fysikdidaktik och astronomi. Hans forskningsbakgrund finns i laboratorieastrofysiken, men han bedriver numera enbart didaktisk forskning. Han leder forskargruppen Learning in Science and Mathematics (LISMA). Hans huvudsakliga forskningsintresse är studenters syn på naturvetenskapens natur, med ett speciellt fokus på deras förståelse för modeller.

\title{
LENA HANSSON
}

Högskolan Kristianstad, Sverige

lena.hansson@mna.hkr.se

\section{Tre elever berättar om universum, gud och fysiken}

\begin{abstract}
The article is about upper secondary students' worldviews and how they relate different contributions to their worldviews to one another. We are especially focusing on contributions from physics and from religion. The context we have chosen for the study is cosmology, which is the frame within which the discussions with the students take place. In this paper we will let three students'stories about existential issues related to cosmology illustrate how the students, when talking about their own views, relate to and handle the views they associate with physics. These students' stories will also illustrate that while atheistic worldviews are supported religious worldviews are put into question, by the students' views of the physics' worldview. This will be discussed together with implications for physics teaching.
\end{abstract}

\section{INTRODUKTION}

Studien som den här artikeln beskriver är en del av ett större projekt som handlar om hur elever hanterar olika bidrag till sin världsbild. Det är rimligt att anta att individen finner bidrag till sin världsbild på många olika ställen, i olika miljöer och i kontakt med olika människor. Ett sådant ställe är i den naturvetenskapliga undervisningen, där eleven möter beskrivningar av den naturvetenskapliga kulturens sätt att studera och tolka fenomen i vår omgivning. Detta utgör för många elever ett nytt och specifikt sätt att se på världen. Helve (1991) menar att man i skolan inte hjälper eleverna att forma sina världsbilder utan lämnar dem med olika fragment som sedan blir svåra för eleverna att själva sätta samman. Att detta är vanligt stöds av att eleverna som deltagit i vår studie uppger att de i skolan inte alls, eller i väldigt liten utsträckning, diskuterat t ex hur naturvetenskap och religion förhåller sig till varandra. En elev som uttrycker detta är Noa som säger så här:

"när vi har haft religion så har man läst religionen och bara accepterat det där. Har man haft fysik så har man läst fysiken och haft det där. Så man tar det i huvudet själv sen" 
Denna artikel handlar om just detta - om vad resultatet blir av att "man tar det i huvudet själv"d v s om hur elever hanterar olika bidrag till sin världsbild och hur de menar att dessa förhåller sig till varandra. Vi fokuserar i projektet, och också i denna artikel, på naturvetenskapliga samt religiösa bidrag.

Förhållandet mellan naturvetenskap och religion har diskuterats av många och olika försök att kategorisera olika typer av synsätt har gjorts. Ett exempel är Barbour (2000) som skiljer mellan fyra olika sätt att se på förhållandet. Dessa kan sammanfattas i konflikt, oberoende, dialog och integration. Görman (1992) menar att man beroende av hur man svarar på grundläggande ontologiska och epistemologiska frågor hamnar i olika situationer där möjligheterna för samexistens respektive konflikt ser olika ut. Den första frågan som Görman lyfter fram handlar om huruvida man uppfattar verkligheten som en eller om man menar att den på något sätt består av olika delar, $t$ ex en materiell och en transcendent värld. I det första fallet finns det bara en verklighet som såväl naturvetenskapen som religionen kan uttala sig om, medan man i det andra fallet kan mena att religionen uttalar sig om den transcendenta världen och naturvetenskapen beskriver den materiella delen av världen. Den andra frågan som Görman lyfter fram handlar om hur man ser på hur man kan få kunskap om denna verklighet och hur den religiösa kunskapen förhåller sig till den naturvetenskapliga. Om man ser på den religiösa kunskapen och den naturvetenskapliga kunskapen som kunskaper av samma slag, eller om man ser dem som helt eller delvis åtskilda kan detta leda till olika slutsatser vad gäller förhållandet mellan naturvetenskap och religion. Man kan också ha ett synsätt där man menar att religionen inte ger någon kunskap överhuvudtaget utan i stället sysslar enbart med t ex etiska frågor. De fall där konflikt kan uppkomma är när naturvetenskapen och religionen gör anspråk på att uttala sig helt eller delvis om samma verklighet och helt eller delvis om samma frågor. I dessa fall kan, men behöver inte, konflikt uppkomma, beroende på synen på religiösa föreställningar samt på synen på naturvetenskapens anspråk.

Svaren på de här grundläggande ontologiska och epistemologiska frågorna kommer alltså att leda till olika slutsatser vad gäller förhållandet mellan naturvetenskap och religion. I detta blir såväl naturvetenskapens som religionens anspråk viktiga. Ur ett naturvetenskapligt didaktiskt perspektiv blir då en intressant fråga vilken typ av svar på de här grundläggande frågorna som elever förknippar med naturvetenskapen och vad detta kan få för konsekvenser för deras vilja att bli en del av den naturvetenskapliga kulturen (Aikenhead, 1996).

Elevers/studenters uppfattningar om relationen mellan naturvetenskap och religion har studerats tidigare (t ex Dagher \& BouJaude, 1997; Esbenshade, 1993; Fysh \& Lucas, 1998; Loving \& Foster, 2000; Roth \& Alexander, 1997; Shipman, Brickhouse, Dagher \& Letts, 2002). I den här studien har ett specifikt område med anknytning till fysik/naturvetenskaplig undervisning, nämligen kosmologi, valts som en ram för samtalen med eleverna. Området har valts eftersom det är nära knutet till existentiella frågor för många människor. I studien av Fysh och Lucas var det också ett av områdena (tillsammans med evolutionen) som nämndes av eleverna som områden som orsakar konflikt mellan naturvetenskap och religion i klassrummet. Dessutom finns det bara en begränsad mängd forskning på elevers uppfattningar av kosmologiska frågeställningar (Lemmer, Lemmer \& Smit, 2003; Shipman et al., 2002; Spiliotopoulou \& Ioannidis, 1996). Förutom en bred fråga om huruvida man kan ha en naturvetenskaplig syn på universum och samtidigt ha en religiös övertygelse, diskuterar vi med eleverna i denna studie också frågor om huruvida en gud kan existera och i så fall vad denna gud har för påverkansmöjligheter ( $\mathrm{t}$ ex skapade gud universum och kan gud ingripa genom att utföra mirakel) och huruvida universum har en mening.

Världsbild kan betraktas som en aspekt av det vidare begreppet kultur - en aspekt som vi menar kan ha stor betydelse för lärande och undervisning i naturvetenskap. Cobern och Aikenhead (1998) har beskrivit elevernas möten med den naturvetenskapliga undervisningen som ett möte mellan två kulturer, nämligen den naturvetenskapliga kulturen och elevens egen kultur. Den nya kulturen som eleverna möter kan vara mer eller mindre i harmoni med elevernas egna kulturer. 
Undervisningen blir då antingen "supportive or disruptive" (Cobern \& Aikenhead, 1998, s. 41). Om kulturerna harmonierar blir resultatet "enculturation". I annat fall kan lärande ändå ske, då genom "assimilation" d v s till priset av att eleven tvingas överge eller undertrycka sin egen kultur, vilket Cobern och Aikenhead menar är negativt (observera att innebörden av begreppet "assimilation" här skiljer sig från samma ords innebörd hos t ex Piaget (Piaget, 2003) och Ausubel (Novak, 2002)). Många elever väljer också att stå emot skolans undervisning - d v s de väljer att inte lära sig. Man har i litteraturen fört fram alternativa sätt att lära naturvetenskap i form av "crosscultural learning" (Aikenhead, 1996; Cobern \& Aikenhead, 1998). Detta alternativa sätt att lära naturvetenskap kan förekomma antingen i form av att individen väljer att införliva valda delar av den naturvetenskapliga kulturen med sin egen men väljer att låta andra vara ("autonomous acculturation"), eller i form av att eleven studerar naturvetenskapen utifrån ungefär så som en antropolog studerar en främmande kultur - alltså utan att själv ta den till sig ("anthropological learning"). "Crosscultural learning" ger alltså eleven möjlighet att förstå naturvetenskapliga resonemang, modeller och utgångspunkter utan att göra dessa till sina egna sätt att se på världen. Man ser undervisning utifrån de olika varianterna av "crosscultural learning" som alternativ till att "school science traditionally attempts to enculturate or assimilate students into the subculture of science" (Aikenhead, 1996). Det senare innebär, till skillnad från "crosscultural learning" att eleven förväntas att fullständigt ta till sig de naturvetenskapliga synsätten och göra dem till sina egna. Aikenhead (1996) menar att det är önskvärt att "crosscultural learning" lyfts fram i undervisningen som alternativa sätt att närma sig naturvetenskapen. Vi har tidigare visat att elever på kosmologiområdet mycket väl själva kan ha ett annat synsätt än det de förknippar med fysiken (Hansson \& Redfors, i tryck). Vi visar där på exempel där elever själva har lärt sig på ett sätt som kan beskrivas som "autonomous acculturation" respektive "anthropological learning".

Kulturmöten kan studeras genom att intervjua lärare och elever om deras synsätt och jämföra dessa synsätt med varandra (Cobern \& Aikenhead, 1998). I det här projektet har vi använt oss av en annan strategi (se också Hansson \& Redfors, 2005a, i tryck). Vi låter eleverna själva berätta för oss hur de ser på fysikens syn på olika frågor. På detta sätt följer vi Marton och Booth (1997) när de argumenterar för att den värld som existerar för människor är den upplevda världen. Det är i relation till denna som människor handlar. Konsekvensen av detta blir att när eleverna bestämmer sig för huruvida den naturvetenskapliga världsbilden är något för dem, så grundar sig beslutet på deras bild av vad denna innebär och inte på lärares eller forskares syn på samma sak.

Vi har tidigare visat (Hansson \& Redfors, 2005a) att det är vanligt att eleverna i vår studie förknippar fysiken med scientism. Vi använder begreppet scientism som Poole (1998). Han diskuterar skillnader mellan science och scientism. Scientism till skillnad från science "Denies that anything other than the natural world exists" och "Denies that there could ever be behaviour other than law like (anti-miraculous)", vidare så säger man inom scientism att "Scientific accounts are all there are" (Poole 1998 s. 195). Exempel på scientistiska synsätt som vi sett elever förknippa med fysiken (Hansson \& Redfors, 2005a) är att allting har en naturvetenskaplig förklaring, att man inte ska tro på sådant som inte bevisats och att en gud därför inte kan existera. För de elever som förknippar sådana föreställningar med fysiken så är det alltså (enligt resonemanget ovan) denna bild av fysiken som eleverna, i den mån de försöker relatera sina egna uppfattningar till naturvetenskapens/fysikens, tvingas att hantera.

Den här artikeln handlar om tre olika elever som alla förknippar scientistiska synsätt med fysiken. Vi visar med elevberättelser hur de ser på huruvida en gud existerar och dennes påverkansmöjligheter (t.ex. mirakel), huruvida universum har en mening och huruvida det är möjligt att ha en naturvetenskaplig syn på universum och samtidigt ha en religiös övertygelse. Syftet är att med dessa tre elevers berättelser illustrera:

1) hur elever som förknippar scientistiska synsätt med fysiken på olika sätt kan relatera till och hantera naturvetenskapens synsätt ( $\mathrm{d}$ v s deras bild av dessa) när de beskriver sin egen syn 
2) hur den fysik som eleverna möter ( $\mathrm{d} v \mathrm{~s}$ deras bild av denna) kommer att stödja somliga världsbilder, medan andra kommer att ifrågasättas.

\section{METOD OCH GENOMFÖRANDE}

Datamaterialet som den här artikeln bygger på kommer från en större studie som har genomförts bland gymnasieelever. Eleverna i denna studie kommer från tre kommunala gymnasieskolor i olika orter i Sverige och de går sista året på naturvetenskapsprogrammet. Detta är ett brett program och eleverna läser många fler ämnen vid sidan av de naturvetenskapliga (Skolverket, 2000). Inom ramen för ett nationellt program har eleverna i Sverige många valmöjligheter. Alla eleverna i den här studien har valt att läsa den mest avancerade allmänna fysikkursen (Fysik B). Universums övergripande utveckling omnämns i kursplanerna för fysikämnet, men behandlas oftast bara ytligt. Förhållandet mellan naturvetenskap/fysik och religion behandlas inte explicit i kursplaner eller beskrivningar av fysikämnet. Däremot säger man att "Utbildningen syftar / .../ till fördjupad kunskap om fysikens roll för utvecklingen av människans världsbild" (Skolverket, 2000). Områdena som gränsar till existentiella frågor kan ha diskuterats i andra kurser också - alla elever på naturvetenskapsprogrammet läser en kurs i religionskunskap och vissa väljer att läsa kurser i t ex filosofi.

88 elever har inom ramen för studien svarat på skriftliga frågor. Frågeformuläret bestod av nio olika frågor (de flesta av dem öppna) och handlade om universums uppkomst och utveckling samt existentiella frågor kopplade till detta. Detta inkluderar frågor om elevernas syn på huruvida det är möjligt att en gud eller högre makt påverkar t ex genom att utföra mirakel, huruvida universum har en mening och huruvida man kan ha en naturvetenskaplig syn på universum och samtidigt ha en religiös övertygelse. De flesta av frågorna bestod av två delar. I den första bad vi eleverna att beskriva fysikens syn på frågan och i den andra bad vi dem beskriva sin egen syn på samma sak. Vi ser fysiken som en kultur (Aikenhead, 1996) med synsätt och värderingar. "Fysikens syn" står i denna artikel för dessa synsätt. Genom att fråga både om elevens egen syn och om vad de menar att fysikens syn på samma sak är så håller vi i designen öppet för att eleverna själva kan ha en annan syn på de här frågorna än den de förknippar med fysiken.

Tolv av eleverna som besvarade de skriftliga frågorna har också intervjuats. Intervjuerna var semistrukturerade och behandlade samma områden som de skriftliga frågorna. Även om intervjuaren såg till att samtalen med eleverna höll sig till dessa intresseområden så tilläts eleverna berätta relativt fritt om sina synsätt och dra paralleller som för dem kändes relevanta. Intervjuaren kunde också ställa frågor som inte funnits bland de skriftliga frågorna, men som bedömdes vara väsentliga. Intervjuerna handlade (på samma sätt som enkäterna) både om elevens egna synsätt och om de synsätt som hon eller han förknippar med fysiken. Synsätt som eleverna ger uttryck för i enkäter och intervjuer har kategoriserats (Hansson \& Redfors, 2005a, i tryck).

Intervjupersonerna valdes av praktiska skäl (enkäten genomfördes på den tredje skolan mycket nära läsårsslutet) bland eleverna på två av skolorna. På dessa två skolor valdes eleverna bland dem som var villiga att delta (33 av de 52 eleverna på dessa två skolor var villiga att delta (63 \%)). Bland dessa elever försökte vi också välja elever som beskrivit olika synsätt i sina skriftliga svar. På detta sätt strävade vi efter att maximera variationen av olika synsätt (Marton \& Booth, 1997) som vi genom intervjuerna kunde få en djupare förståelse för. Intervjuerna gör det också möjligt för oss att få en bättre förståelse för en individs övergripande resonemang och synsätt, eftersom förståelsen för elevens sätt att resonera och se på världen blir mer nyanserat och djupare genom intervjun.

Intervjuerna har transkriberats. Vi har sedan konstruerat berättelser, skrivna i jag-form, baserade på vår förståelse av de resonemang och synsätt som eleverna uttrycker. Inspirationen till att skriva 
elevberättelser utifrån intervjuer som löpande text istället för att bara ange enskilda intervjuutdrag kommer från Cobern (2000b), men tillvägagångssättet är inte det samma. Elevberättelserna har skrivits så att de synsätt som eleven presenterar bibehålls (se exempel i appendix A), men hummanden och stakningar anges inte och intervjuarens röst utelämnas. Språket som används i berättelsen ligger mycket nära elevens eget sätt att uttrycka sig. Många gånger har intervjupersonens uttalanden återgetts ordagrant, medan de andra gånger har sammanfattats (t ex har likartade resonemang, upprepningar och exempel, tagits bort). Även när sådana sammanfattningar gjorts ligger dock berättelserna nära intervjuuttalandena. De delar av intervjuerna från vilka de här berättelserna konstruerades var där vi pratade om huruvida en gud existerar, huruvida denna gud kan påverka genom att utföra mirakel, huruvida universum har en mening, och huruvida man kan ha en naturvetenskaplig syn på universum och samtidigt ha en religiös övertygelse.

Vi har i ett annat sammanhang presenterat resultat på gruppnivå (Hansson \& Redfors, 2005a). Här har vi valt att fokusera på mer detaljerade beskrivningar av tre individers synsätt och resonemang. För detta ändamål har tre elevers berättelser valts. Dessa valdes eftersom de alla berättas av mycket verbala elever med mycket att säga om de områden som artikeln behandlar. Vi har tidigare visat att det är vanligt att eleverna förknippar scientistiska synsätt med fysiken (Hansson \& Redfors, 2005a). Med detta som bakgrund valdes de tre berättelserna bland dem i vilka scientistiska synsätt i relativt hög utsträckning förknippas med fysiken. Skälet till detta var att visa på hur elever relaterar till och hanterar en sådan syn på fysiken när de beskriver sina egna synsätt. Valet föll också på berättelser där eleverna uttrycker olika egna synsätt. Medan Lisa relaterar till sin tro på Gud som skapare och Jesus som frälsare, säger Adam uttryckligen att han är ateist. Noa säger sig ha en i grunden kristen tro, men denna kommer under intervjun främst till uttryck i en tro på ett liv efter detta. Pseudonymer används i stället för elevernas riktiga namn.

\section{RESULTAT OCH DISKUSSION}

Tre olika elevberättelser om universum, fysiken, gud och eleverna själva kommer nu att beskrivas. Vi kommer sedan att diskutera hur de här tre eleverna - Noa, Lisa och Adam - på olika sätt relaterar till och hanterar de synsätt som de beskriver som fysikens, när de beskriver sina egna synsätt. Vi kommer också att diskutera vilken sorts världsbilder som stöds och vilka som kommer att ifrågasättas utifrån synsätten som eleverna förknippar med fysiken. Vi börjar med Noas berättelse.

\section{Noas berättelse}

Jag tror inte att det finns någon mening med universum. Människan är bara en organism som fått medvetande om dess existens. En cell eller en sån liten organism lever ju bara ett liv liksom. Den har inget mer syfte med det. Det är bara människan som fått ett medvetande och tänker mer på varför vi är här. Jag tror inte att det finns någon mening egentligen. Evolutionen har gått så långt att vi blivit medvetna om att vi finns till. Men någon direkt mening finns inte. Jag tror inte att fysiken ser någon direkt mening heller.

Jag tror inte att mirakel och under inträffar. Om man går efter vetenskapen så går det att förklara. Som vi ser det är allting uppbyggt av lagar. Men jag tror nog ändå inte att det alltid är så. Människan har inte den kapaciteten - vi har ju t ex ingen aning om vad universum är för något. Vi kanske inte kan beskriva allt nu, men det går att förklara. Denna uppfattning har fysiken också - det ska gå att förklara det. Mirakel tror jag inte förekommer, utan det som ser ut som ett mirakel är bara en tillfällighet.

Jag tycker att det är möjligt att ha en naturvetenskaplig syn på universum och samtidigt ha en religiös övertygelse. Kanske kan man inte vara blint troende, men många går i kyrkan och är mest religiösa av personliga skäl. Man har en egen tro för att få hopp. Men en riktigt inbiten fysiker kanske inte vill ha en tro - han vill inte tro att det finns något sånt. Men det är mycket upp till personen tror jag. Innerst inne tror de nog på något. Att inte bara se det som att efter livet är det slut, utan tänka att vi 
kommer att leva ett nytt liv efter detta gör ju livet lättare. Det är nog för deras egen skull bra att ha en någon sorts tro också och inte bara gå runt och gräva ner sig i att vi lever i en värld av lagar och vi kommer inte att göra något mer än detta. Vi känner ju inte till allt i universum - det kan finnas något övernaturligt som vi inte förstår eller kan beskriva. Man kan ju inte vara säker. Men en fysiker hade nog menat att Gud inte startade universum. Det är istället processer och reaktioner. Det ser man ju bara på människan att det är en massa kemiska reaktioner och allting är liksom elektriska impulser och allt sånt så att någon gud så direkt tror jag inte finns.

Jag tror ju inte att det sitter en man där uppe och tittar ner på oss. Men i grund och botten finns det väl någonting litet som säger i alla fall att något, något finns där kanske. Men det är antagligen för att den religionen vi har är så utbredd här. Hade jag bott $i$ Indien hade jag kanske varit hindu i stället och hade jag bara haft vetenskapen så hade jag nog bara haft den tron. Men eftersom jag lever här har jag i grunden en kristen uppfattning att det någonstans kanske finns någonting, kanske någonting efter döden. Man har ju hört om flera som varit avlidna ett kort tag och sedan sagt att de gått mot en tunnel med ljus - så kanske är det någonting. Det är trots allt energi som löper runt i människan och den energin måste ju ta vägen nånstans.

En gud eller högre makt har överhuvudtaget ingen påverkan på universum. Likadant är det omöjligt att det är förutbestämt, som jag ser det. Detta eftersom allting bara är processer egentligen som jag uppfattar det alltså med kemin och fysiken och allting sånt - att allt är regler och processer och relationer och allt möjligt - så tror jag att det är omöjligt att någonting kan vara förutbestämt. Sedan är det möjligt - det kan vara något som vi inte förstår som binder samman grejerna. Men jag tror i alla fall inte att det kan var någon som kan påverka förloppet.

Vi har i fysiken inte behandlat de existentiella frågorna eller frågan varför. Det har i så fall varit att så här är det och så vidare, haft bara lite formler och sånt som räknar på det. Det har mer varit på ytan så inga mer djupgående grejer. Vi har säkert tagit upp Big Bang men inte i syfte att lära oss alltså egentligen vad det var för någonting, det har vi ju inte haft så i fysiken direkt. Fysiken är mer matteliknande att man sitter och räknar och tar upp teorier och försöker använda dem, att mer bara känna till begreppen och sånt har det varit.

Vi har aldrig i skolan pratat om huruvida man kan kombinera naturvetenskap och religion eller gjort jämförelser mellan dem. I konfirmationsundervisningen läste man att Gud skapade jorden på sju dagar osv. Men det hade man ju förstått redan då, när man läst teoretiska ämnen, att det inte är så. Men jag har egentligen aldrig pratat och jämfört i skolan. Det har mer varit så att när vi har haft religion så har man läst religion och när man har haft fysik så har man läst fysik. Så man tar det $i$ huvudet själv sen.

Vad man kan se i Noas berättelse överensstämmer hans egen syn i stort med den han beskriver som fysikens. Man får dock intrycket att han gärna vill tro på något mer, men att gränserna för vad han känner att han kan tro på sätts av naturvetenskapen. Han ser det därför inte som möjligt att en gud existerar som kan ha skapat universum, påverkat dess utveckling eller kan ingripa i form av mirakel. Han menar att naturvetenskapen säger oss att allt bara är processer och att det finns förklaringar till allt. Detta återkommer också vad gäller meningsfrågan. Han vill gärna tro att det finns någon mening, men detta blir svårt eftersom han ser det som klarlagt att allting bara är processer. Det som finns kvar av det som han säger är en i grunden kristen tro är en tro på något efter detta liv, vilket han inte tycker fysiken/naturvetenskapen motsäger. Tvärtom finner han där stöd för att energi inte kan försvinna, utan måste finnas kvar i någon form. Detta öppnar för honom en möjlighet att livet kan fortgå på något sätt, även efter döden.

Vad Noa i sin berättelse gör är att han förknippar en ontologisk reduktionism med fysiken/naturvetenskapen: man har visat att allt bara är processer. Här sker en hopblandning av en metodolo- 
gisk reduktionism som är en del av naturvetenskapens arbetsmetod, med en ontologisk reduktionism som inte är nödvändig för naturvetenskapen (Poole, 1985). Ontologisk reduktionism

"claims that the atom-and-molecule story is the only valid description - or at any rate the best description - of any phenomenon under question"

(Poole, 1985, s.255).

Noa förknippar också fysiken med ett epistemologiskt grundantagande om att allt kan förklaras med lagar. Detta blir dock för honom också ett ontologiskt antagande - händelser som inte följer lagarna inträffar inte. Inte heller detta är ett antagande som av nödvändighet måste förknippas med fysiken. För den enskilde individen - som t ex för Noa - är det naturligtvis antaganden som man kan göra om världen. Man får dock, genom hans berättelse, en känsla av att detta snarare utgör en ram för hans tänkande - en ram som han upplever är satt av naturvetenskapliga sanningar. För honom kommer den här bilden då att ställas mot en religiös världsbild och han får ingen hjälp att relatera dessa potentiella bidrag till sin världsbild till varandra. Detta diskuterar Helve (1991) som menar att skolan ger fragment, men ingen hjälp till eleverna att förhålla dessa till varandra - man får som Noa säger "ta det i huvudet själv". I Noas berättelse blir hans bild av naturvetenskapen en ram för tänkandet som minskar möjligheten att tro på något annat. Det finns anledning att tro att den naturvetenskapliga världsbilden så som den förstås av Noa inte har fungerat enbart som ett stöd för hans egen världsbild utan att han har tagit till sig denna åtminstone delvis motvilligt och på bekostnad av andra saker han gärna skulle vilja tro på. Detta kan ses som ett exempel på assimilation (Aikenhead, 1996).

\section{Lisas berättelse}

[Lisa tror på en gud som har skapat det allra första i universum. Därefter tror hon att universum har utvecklats så som fysiken säger. Gud har planerat allt från början. Universum är så välplanerat att Gud sedan inte behöver ingripa i den storskaliga utvecklingen.]

Fysiken tror ju inte att det kan ske mirakel för de vill ju förklara det. När det t ex står i bibeln om mirakel, som att de flyttar på vatten i floden, så förklarar fysikerna det med att det kan ha skett så och så. Jag tror ju också på det som de säger, men att det var Gud som var anledningen till att det skedde. Men Gud gör det på ett sätt som går att förklara vetenskapligt. Jag tror att mycket av det som står i bibeln om Jesus och så är överdrivet. Saker som vi idag inte skulle se som mirakel, som t ex örter som botade förkylningar eller att en överviktig skulle kunna ha blivit botad genom att äta annorlunda. Det finns alltså vetenskapliga förklaringar till dessa mirakel. Gud kan ju göra saker som inte har en vetenskaplig förklaring också, men han undviker att göra det. Jag tycker att det kan hända mirakel, stora grejer, nu också men det är det att detta bara är en av alla stora grejer som händer, så vi kallar inte det mirakel. Fysiken tror inte på mirakel som inte har en vetenskaplig förklaring. Har någonting hänt så försöker de ta reda på vad som har hänt vetenskapligt. Får man inte reda på det så tror jag inte att de tror på det. Jag tror ju själv på Gud, men samtidigt ser jag väldigt vetenskapligt på allting. Därför blir det så att om det står någonting i bibeln som man inte kan förklara, så tror jag att det är överdrivet, som att $t$ ex en dag kanske egentligen är ett halvår eller så. Jag tror inte på exakt vad det står. Man kanske skulle kunna säga att Jesus kanske innehade kunskap som man inte egentligen hade då, men som vi kanske har idag - och då är det miraklet.

Jag vet inte hur fysiken ser på om det finns en mening med universum. Men jag kan tänka mig att fysiken ser det som att människan är det högst uppsatta i rangordningen, medan man om man tror på en högre makt så är det ju den som är högst. Människorna är inte högst - de vet inte allt och kommer aldrig att göra det. Jag tror ju att det finns en mening med livet, men jag tror inte att någon människa vet den - utan det vet bara Gud. Jag vet inte om fysiken tror att det finns någon mening, men de borde ju ändå tro att det finns någon mening med livet, men jag vet inte vad de tror. Vi människor kan aldrig förstå meningen med något så stort som universum, vi är ju bara människor. Sedan kan man ju söka 
efter meningen med livet. Det är väl lite så att när fysiker försöker ta reda på hur universum uppkommer och allt sånt där, så är det väl lite det att man söker efter meningen med livet. Så fysiken tror nog att det finns någon mening med livet, men jag vet inte vad fysiken säger om vad det skulle vara.

Angående vad fysiken har för syn på om man kan ha en naturvetenskaplig syn på universum och samtidigt ha en religiös tro så är det ju så att fysiken tror inte på det här med religionen, eftersom de inte tror att det kan hända religiösa saker - för att det måste finnas en förklaring till allting. Så därför kan man inte ha en naturvetenskaplig syn samtidigt som en religiös tro. En fysiker måste ju vilja ta reda på varför eller hur och när - inte bara acceptera utan ifrågasätta allt. Men om man tror på någonting så kan man mer acceptera saker - att det bara är så. Samtidigt har jag ju väldigt svårt att tro att människor inte tror på någonting - att de bara är vetenskapliga. Det måste vara väldigt svårt att hitta en mening om det liksom bara har skett så och så och man inte tror på någonting. Så jag tror ändå att det kanske är många fysiker som ändå tror på någonting också - men de tror ändå mer på fysiken än på det religiösa. Jag tror inte att det kan vara någon som kan tro exakt vad som står i bibeln och samtidigt vara fysiker - så det beror i så fall på hur man tolkar. Jag tror att det är svårt att vara fysiker och samtidigt tro jättestenhårt på allt - men det är klart, det går säkert. Jag själv tror ju på en högre makt, men att det ändå har skett så som vetenskapen säger. Men det finns en högre makt som har koll på allt och som finns överallt och i allt.

Lisas bild är att fysiken menar att allting kan förklaras naturvetenskapligt, och att man inte ska tro på saker som inte är bevisade eller förklarade. Detta synsätt står i motsats till hennes tro på en gud som t ex kan utföra mirakel, eftersom sådana omöjliggörs med synsättet att allt som finns och händer kan förklaras naturvetenskapligt. Fysiken sätter på detta sätt en ontologisk ram som Lisa får hantera och på många sätt tycker hon att den är rimlig. Dock kan hon inte acceptera den fullt ut, eftersom hon också tror att mirakel faktiskt kan ske. På detta sätt är hon mer benägen att rucka på ramarna än Noa är, som mer håller sig inom ramen. Man kan i Lisas berättelse se att hon förhandlar mellan den världsbild som hon förknippar med fysiken och den religiösa världsbilden. Resultatet blir, vad gäller huruvida mirakel kan ske, något av en kompromisslösning. Hennes uppfattning blir att Gud kan utföra mirakel, men att dessa sker mycket sällan och att Gud i de flesta fall handlar på ett sätt som gör att vi kan förklara händelseförloppet vetenskapligt. På samma sätt ser hon på universums hela utveckling som planerad och startad av Gud, men planerad så bra att han sedan egentligen inte behövt ingripa i universums storskaliga utveckling. Hon tror alltså här på vetenskapen men förstår det utifrån en religiös tolkningsram. Lisa praktiserar i hög grad "autonomous acculturation" (Aikenhead, 1996) när hon förhandlar och utifrån olika potentiella bidrag till världsbilden i sin berättelse konstruerar sin syn på hur världen är beskaffad.

\section{Adams berättelse}

Som jag ser det finns det inte en chans att det är möjligt med mirakel eller under. Jag tror fysiken har rätt så bra koll på vad de vet - att de kan förklara det mesta nu och jag tror mycket mer på fysiken, och jag är som jag sagt naturvetare då - jag tror inte på någon högre makt. Jag är outtalad ateist - jag har inte gått ur kyrkan och jag är döpt, men jag tror inte på det. Jag valde att inte konfirmera mig på grund av det. Så jag tror mest på det naturliga - på vad fysiken säger. Så gott som allt är nog möjligt att förklara. Men sedan bibelns ord, kan man ju inte förklara, då Adam tog ett revben och skapade Eva. Det finns inte en chans tror jag. Eller att Gud ska skapa översvämningar och gräshoppesvärmar. Jag tror mer på att det är naturliga orsaker. Jag tror inte att fysiken är så tolerant mot möjligheten med gudomliga ingripanden eller mirakel. Fysikerna har kommit så långt, de har undersökt mycket, fått reda på så många saker, så de anser att de vet det mesta om det. De vet att trädet använder undertryck för att suga upp vatten, all mekanik och all kvantfysik...De tror att de kommer att få reda på det mesta. Galaxiska frågor om universum tar nog för lång tid att räkna ut för att en människa ska hinna med det under sitt liv. Varken han eller hans avkomma så att säga, kommer att hinna räkna ut det. Det skulle ta så lång tid och det skulle finnas så mycket felkällor i det så det skulle inte vara värt att räkna ut, tror jag. 
Jag vet inte om universum enligt fysiken har en mening. Enligt fysiken har väl universum inte någon mening direkt, de tar väl reda på vad som händer, hur det händer och på vilket sätt med sina lagar och sånt. Men jag tror inte att de någonsin får någon förklaring på meningen med universum. Varför vi bara hittat liv på denna planeten. Om det är så stort måste det finnas något område till med intelligenta varelser, men i så fall varför har vi inte hittat dem, eller varför har de inte hittat oss. Så nej någon direkt mening med fysiken [universum] finns det nog inte. När jag var liten så trodde jag att det var någon jätte som hade ett eget spel - jag hade en fantasiförklaring. Att vi bara var spelpjäser, att han flyttade runt oss och spelade med oss. Men nu så tror jag väl inte direkt att det finns någon mening med det. Vi finns och vi får väl vara glada för det, men någon mening finns ju inte. Vi förstör vår planet och har ingen annanstans att ta vägen. Så meningen med universum är väl att dö och att dö ut, att universum dör ut till en ny big bang, sen föds det på nytt igen. Att dö, får bli meningen med universum. [Intervjuaren säger att du har skrivit att du tror att vi har en mening varför skulle vi annars finnas till. Adam svarar då att ja men då är meningen att vi ska dö därför finns vi.] Jaa men vi finns ju av ett skäl, men det måste vi göra. Jag vet inte vad det är för skäl. Att vi skulle fortplanta oss och så, men vi är de enda däggdjuren som inte klarar av att begränsa oss. Alla andra däggdjur flyttar till ett område och sen så förökar de sig tills de är tillräckligt många för området och vad det klarar av och sen så drar de andra vidare. Människan förökar sig och stannar på samma ställe. Det finns ju bara en annan organism, det är bara viruset, som gör likadant. Ingen annan organism gör likadant, så att vi är nog mest här för att dö ut tror jag, sorgligt men sant.

Fysiken tror jag inte direkt har någon religiös övertygelse. Många fysiker har ju haft övertygelser men de har ändå försökt överbevisa det. Galilei blev ju satt i husarrest för att han satte emot kyrkan med sin världsbild att jorden inte var i centrum. Så jag tror att fysiken har en sannare bild än religionen, då kyrkan fortfarande påstår att mannen skapade kvinnan och så. Om fysiken skulle få hitta på en egen religion så tror jag att man skulle kunna kombinera dem, men de som finns idag de strider ju oftast mot fysiken. Det skulle vara en naturvetenskaplig religion - en religion som inte fastställer någonting - säger att så här är det. Att vi uppkommer på grund av evolution och att vi utvecklas och gör oss själva till de vi är - den religionen skulle kunna leva med fysiken tror jag. Men varken kyrkan, islam eller judendomen skulle kunna göra det. Ingen gud skulle kunna få plats. Religion är ju tro på något. Precis som andra är övertygade om att Gud skapade så kan de vara övertygade om att big bang skapade - man tror som fysiken.

Jag tycker att man kan dra en massa exempel där det går att kombinera naturvetenskap och religion och en massa där det inte går. En hel kvinna kan inte skapas av ett revben, det går inte enligt fysikens lagar för det krävs mycket mer grundämnen, mycket mer materia t ex. Men ändå man vet inte vad själen är för något, vet inte om den består av något, vet ingenting fysiskt om den. Den skulle kunna finnas ändå och religionen är ju starkt troende på själar. Så det är ju möjligt att den finns ju. Precis som man på 1500 -talet började leta efter själen i kroppen och inte hittade den, men så brukar de motsätta sig kyrkan. Så själen kan ju finnas ändå, men vi har inga bevis för att den finns - det är bara att tro liksom - att själen är vårt riktiga jag. Universums uppkomst är ett exempel på något som inte går att kombinera. Kristendomen säger att Gud skapade jorden på sju dagar. Det tror jag inte så mycket på för det tog bra mycket längre tid att skapa världen än sju dagar. Jag tror att de flesta människor skulle vara ense med mig om att man inte kan skapa jorden på sju dagar, men jag vet inte det finns säkert flera andra tankar om huruvida man kan kombinera naturvetenskap och religion. Min tanke är att det inte går.

Det första jag har fått höra var på kyrkans barntimmar - att Gud skapade det - det har jag nog faktiskt aldrig trott på. Sedan i skolan i ettan eller tvåan fick vi reda på big bang - de första delarna - sedan har jag väl alltid trott på det.

Adam beskriver en ateistisk världsbild - men håller lite öppet för att det $\mathrm{t}$ ex kan finnas en själ. Han får stöd i sin övertygelse att det inte finns någon gud av det som han uppfattar som fysikens världsbild. Naturvetenskapen kan enligt honom inte kombineras med en tro på en gud. Mirakel är 
inte heller möjliga enligt honom och han får stöd också i detta av att han ser det som att fysikens syn är att allt som finns kan eller kommer att kunna förklaras naturvetenskapligt. Vad gäller mening tvekar han något och är en stund inne på att vi måste finnas till av något skäl, men återgår sedan till att prata om mening på ett reduktionistiskt sätt - att meningen med universum är att det föds och sedan dör osv. Detta blir en del av hans cykliska syn på universum.

Vad gäller de aspekter som tas upp i den här artikeln blir den världsbild som Adam förknippar med fysiken i stort oproblematisk för honom och hans ateistiska syn på världen stöds av denna: "jag är som jag sagt naturvetare då - jag tror inte på någon högre makt". Den världsbild som han uppfattar som naturvetenskapens har tagits upp av honom och blir ett stöd för hans egen världsbild. Detta kan beskrivas som "enculturation" (Aikenhead, 1996).

\section{AVSLUTANDE DISKUSSION OCH IMPLIKATIONER FÖR UNDERVISNING}

De tre eleverna relaterar i sina berättelser till fysiken/naturvetenskapen när de beskriver sin egen syn på existentiella frågor kopplade till kosmologiområdet. Det som förknippas med naturvetenskapen/fysiken fungerar på olika sätt som en ram för de tre naturvetarelevernas egna synsätt. Vi har dock sett att denna ram kan tolkas och hanteras på olika sätt av eleverna. Medan ramen för Noa blir en relativt tydlig gräns som inte kan ruckas på, förhandlar sig Lisa mer fram till en position där hon tar hänsyn till både element från en religiös världsbild och till de synsätt som hon förknippar med naturvetenskapen/fysiken. För Adam blir naturvetenskapen i stället ett stöd för hans egna synsätt.

I de tre elevernas berättelser som vi här tagit del av förknippas fysiken med scientism innefattande t ex att allting har en naturvetenskaplig förklaring, att man inte ska tro på saker som ej bevisats eller förklarats, samt en ontologisk reduktionism. Dessa grundantaganden om världen används för att förklara varför en gud, enligt fysiken, inte kan existera och t ex utföra mirakel och varför universum enligt fysiken inte har någon mening. Det blir i de tre elevernas berättelser tydligt att konsekvensen av detta blir att ateistiska världsbilder är det som naturvetenskapen/fysiken upplevs stödja. Religiösa världsbilder däremot kommer att ifrågasättas av deras bild av vad som kännetecknar en naturvetenskaplig/fysikalisk världsbild. Detta kan tänkas få konsekvenser och vara problematiskt för en del elever som har en religiös tro och samtidigt studerar naturvetenskapliga ämnen i skolan.

Vi har sett att Noa i mycket har anpassat sig till den ram som han upplever ges av naturvetenskapen. Ur hans berättelse får man en känsla av att han gärna hade velat tro på något mer, men att hans bild av naturvetenskapen har gjort att en religiös tro har undertryckts. De elever som förknippar fysiken med scientism och samtidigt själva har religiösa världsbilder, står när de försöker relatera dessa till varandra inför ett val. Antingen kan de undertrycka den religiösa världsbilden (så som Noa tycks göra) alternativt stå utanför den naturvetenskapliga kulturen, eller så kan de tillämpa olika varianter av "crosscultural learning" (Aikenhead, 1996). Ett exempel på det senare är Lisa som i sin berättelse visar att hon förhandlar, kompromissar och förstår de delar av den vetenskapliga världsbilden som hon tar till sig utifrån en religiös tolkningsram.

Vi menar att "crosscultural learning"- strategier, som t ex de som används av Lisa, är bra när elevernas världsbilder skiljer sig från fysikens/naturvetenskapens, i och med att de öppnar möjligheter för elever att lära naturvetenskap på ett meningsfullt sätt utan att nödvändigtvis ta den till sig. Att lägga upp naturvetenskaplig undervisning på ett sådant sätt skulle antagligen hjälpa många elever. Vad gäller de grundantaganden om världen som belysts och förknippats med naturvetenskapen i de elevers berättelser som lyfts fram här, hade denna typ av strategier dock inte varit nödvändigt. "Scientistiska" synsätt hör inte till dem som utgör nödvändiga grundantaganden för naturvetenskapen (Cobern, 2000a; Poole, 1998). Bara när eleven inte delar de grundantaganden 
om hur världen är som är nödvändiga för naturvetenskapen blir dessa sätt att lära naturvetenskap rimliga. Vi bör i den naturvetenskapliga undervisningen hjälpa eleverna genom att diskutera vilka grundantaganden som är nödvändiga för naturvetenskapen och vilka som inte är det. De grundantaganden som verkligen utgör en nödvändig grund för naturvetenskapen kan vara förenliga med mer än en världsbild - mer än en världsbild är kompatibel med naturvetenskapen (Cobern, 1996). Diskussioner om det här i det naturvetenskapliga klassrummet kan förhoppningsvis leda till att fler elever känner att deras syn på världen respekteras och inte hotas av den naturvetenskapliga undervisningen. Vi har i ett annat sammanhang (Hansson \& Redfors, 2005b) beskrivit ett sätt att genomföra den här typen av diskussioner inom ramen för skolans naturvetenskapliga undervisning. Ett sådant resonemang bör leda till att fysiken/naturvetenskapen som sådan inte upplevs ge ett starkare stöd för t ex Adams än för Lisas världsbild.

\section{REFERENSER}

Aikenhead, G. S. (1996). Science Education: Border Crossing into the Subculture of Science. Studies in Science Education, 27, 1-52.

Barbour, I. G. (2000). When Science Meets Religion. New York: HarperCollins.

Cobern, W. W. (1996). Worldview Theory and Conceptual Change in Science Education, Science Education, 80(5), 579-610.

Cobern, W. W. (2000a). The Nature of Science and the Role of Knowledge and Belief. Science \& Education, 9, 219-246.

Cobern, W. W. (2000b). Everyday Thoughts about Nature. Dordrecht: Kluwer Academic Publishers..

Cobern, W. W., \& Aikenhead, G. S. (1998). Cultural Aspects of Learning Science. I H. J. Fraser och K.G. Tobin (Red.), The International Handbook of Science Education (s. 39-52). Dordrecht: Kluwer Academic Publishers.

Dagher, Z. R., \& BouJaude, S. (1997). Scientific Views and Religious Beliefs of College Students: The Case of Biological Evolution. Journal of Research in Science Teaching, 34(5), 429-445.

Esbenshade, D. H. (1993). Student Perceptions about Science \& Religion, The American Biology Teacher, 55(6), 334-338.

Fysh, R., \& Lucas, K. B. (1998). Religious Beliefs in Science Classrooms. Research in Science Education, 28(4), 399-427.

Görman, U. (1992). Teologer och naturvetenskap. I U. Görman, L. Haikola \& T. Sundström, Kompendium i naturvetenskap och religion (s. 101-143). Lund: Teologiska institutionen, Lunds universitet.

Hansson, L. \& Redfors, A. (i tryck). Swedish upper secondary students' views of the origin and development of the universe. Research in Science Education.

Hansson, L. \& Redfors, A. (2005a). Physics and the possibility of a religious view of the universe - Swedish upper secondary students' views. Manuscript submitted for publication.

Hansson, L. \& Redfors, A. (2005b). Upper secondary students in group discussions about physics and our presuppositions of the world. Manuscript submitted for publication.

Helve, H. (1991). The Formation of Religious Attitudes and World Views: A Longitudinal Study of Young Finns. Social Compass, 38(4), 373-392.

Lemmer, M., Lemmer, T. N., \& Smit, J. J. A. (2003). South African students' views of the universe. International Journal of Science Education, 25(5), 563-582.

Loving, C. C., \& Foster, A. (2000). The Religion-in-the-Science-Classroom Issue: Seeking Graduate Student Conceptual Change. Science Education, 84, 445-468.

Marton, F., \& Booth, S. (1997). Learning and Awareness. Mahwah, N. J.: Lawrence Earlbaum Associates.

Novak, J. D. (2002). Meaningful Learning: The Essential Factor for Conceptual Change in Limited or Inappropriate Propositional Hierarchies Leading to Empowerment of Learners. Science Education, 86(4), 548-571. 
Piaget, J. (2003). Development and Learning. Journal of Research in Science Teaching 40(S1), S8S18 (originally published in 1964, Journal of Research in Science Teaching 2(3), 176-186).

Poole, M. W. (1985). Science education and the interplay between science and religion. School Science Review, 85, 252-261.

Poole, M. W. (1998). Science and Science Education: a Judeo-Christian Perspective. I W. W. Cobern (red.), Socio-Cultural Perspectives on Science Education. An International Dialogue (s. 181-201). Dordrecht: Kluwer Academic Publishers.

Roth, W-M., \& Alexander, T. (1997). The interaction of students' scientific and religious discourses: two case studies. International Journal of science education, 19(2), 125-146.

Shipman, H. L., Brickhouse, N. W., Dagher, Z., Letts IV, W. J. (2002). Changes in Student Views of Religion and Science in a College Astronomy Course. Science Education, 86, 526-547.

Skolverket (2000). Naturvetenskapsprogrammet - Programmål, kursplaner, betygskriterier och kommentarer. Stockholm: Fritz

Spiliotopoulou, V., \& Ioannidis, G. (1996). Primary Teachers' Cosmologies: The Case of the 'Universe'. I G. Welford, J. Osborne \& P. Scott (Red.). Research in Science Education in Europe: Current Issues and Themes (s. 337-350). London: Falmer Press.

\section{APPENDIX A. EXEMPEL PÅ BERÄTTELSERNAS RELATION TILL INTERVJUTRANSKRIPTEN.}

\section{Intervjutranskript}

Exempel 1:

Intervjuare: $m m$ och det är då möjligt att ...med det tänker du att det är möjligt att förklara allt som händer med hjälp av fysiken?

Elev: Allt som händer. Tja, det är mycket som händer men så gott som allt är nog möjligt att förklara

Intervjuare: med mer

Elev: men sen så bibelns ord kan man ju inte förklara då Adam tog ett revben och skapade Eva, det finns ju inte en chans tror jag

Intervjuare: med mer

Elev: även om jag har mött eh personer som är helt övertygade om att de har ett revben mindre än vad kvinnorna har

Intervjuare: $\mathrm{mm}$

Elev: pågrund av bibeln så tror jag inte mycket på det

Intervjuare: nej

Elev: det gör jag inte. Och att Gud ska skapa översvämningar och gräshoppesvärmar. Det tror jag mer på att det är naturliga...

Intervjuare: $\mathrm{mm}$

Elev: orsaker

\section{Elevberättelse}

Exempel 1:

Så gott som allt är nog möjligt att förklara. Men sedan bibelns ord, kan man ju inte förklara, då Adam tog ett revben och skapade Eva. Det finns inte en chans tror jag. Eller att Gud ska skapa översvämningar och gräshoppesvärmar. Jag tror mer på att det är naturliga orsaker. 
Intervjuare: [harkling] hade jag en fråga om det här med om universum har mening

Elev: mm.....aha

Intervjuare: vad säger fysiken om det tror du?

Elev: ehm....jag vet inte om fysiken så här..det vet jag ingenting om men jag kan tänka mig så med att fysiken tycker så att människor liksom är det viktigaste

Intervjuare: $\mathrm{mm}$

Elev: eller vad man ska säg, att dem det är liksom de som är högst, högst uppsatta eller om man säger så liksom i rangordningen

Intervjuare: $\mathrm{mm}$

Elev: medan man då tror liksom så på en högre makt så är det ju det som är högst

Intervjuare: $\mathrm{mm}$

Elev: att liksom människor är liksom inte ...högst de vet inte...de vet inte allt

Intervjuare: nej

Elev: och det kommer de liksom [ha] aldrig att göra Intervjuare: nej

Elev: jag tror ju att asså JAG tror ju att det finns mening med livet ja fast jag tror ju inte att det är någon människa som vet den och jag tror inte att det är någon som kommer att få reda på den heller för det är liksom bara Gud.. som vet det
Jag vet inte hur fysiken ser på om det finns en mening med universum. Men jag kan tänka mig att fysiken ser det som att människan är det högst uppsatta i rangordningen, medan man om man tror på en högre makt så är det ju den som är högst. Människorna är inte högst - de vet inte allt och kommer aldrig att göra det. Jag tror ju att det finns en mening med livet, men jag tror inte att någon människa vet den - utan det vet bara Gud. 